Volume I Tahun 2021

November 2021
E-ISSN: 2808-5361 http://e-journal.fkmumj.ac.id/
Proceeding The First

Muhammadiyah Internasional-

Public Health and Medicine

Conference

\title{
Fast Food Consumption Behavior in Adolescents
}

\author{
${ }^{1}$ Afiah Fakhira, ${ }^{2}$ Alfiah Ismiana, ${ }^{3}$ Annisaa, ${ }^{4}$ Audia Lestari \\ Faculty of Public Health, Muhammadiyah University of Jakarta \\ K.H. Ahmad Dahlan St, Cireundeu, Ciputat, South Tangerang, 15419 \\ Email: lestari.audia1105@gmail.com
}

\begin{abstract}
The nutritional needs of adolescents need to be considered because during adolescence there is rapid growth and development. Unhealthy eating habits will affect the nutritional intake of adolescents. Unhealthy foods such as fast food are consumed by teenagers. At a time when everything is as modern as it is now, teenagers want everything fast-paced, including choosing food fast food is also kn own to the public as junk food. Junk food is defined as junk food or food that has no nutrition for the body. Eating junk food is not only useless but can also be detrimental to health. Fast food comes from western countries which generally have high fat and calorie content. Descriptive research method with a qualitative approach to the method of phenomenology. The sample in this study was four (4) students consisting of one grade 1 high school, two grade 2 high school students, and 1 grade 3 senior high school student. This study wants to explore the phenomena experienced by students in consuming fast food. Many factors influence teenagers to consume fast food. These factors are discussed based on research articles and book references. Factors that influence the consumption of fast food include taste, price, comfortable place, and the influence of peers. Fast food can increase the risk of several diseases, such as obesity, diabetes, hypertension, and blood lipid disorders or dyslipidemia. Obesity or overweight is experienced by many children, adolescents, and adults. Obesity occurs due to changing lifestyles, including eating patterns that often eat fast food. Eating fast food too often does not only lead to obesity. However, obesity experienced by a person will increase a person's risk factors for suffering from other degenerative diseases, such as high blood pressure, diabetes, cancer, heart disease, and stroke.
\end{abstract}

Keywords: Teenager, Fast Food, Obesity, Indonesia 
E-ISSN: 2808-5361 http://e-journal.fkmumj.ac.id/
Proceeding The First Muhammadiyah InternasionalPublic Health and Medicine

Conference

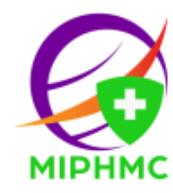

\section{INTRODUCTION}

Adolescents are people who are between the ages of 10 and 19 years32. According to the Regulation of the Minister of Health Number 25 of 2014, adolescents are the age group of 10 years to 18 years. Adolescence begins at age 12 and ends around age 17 or 1829. Adolescents have special nutritional needs compared to other age groups. This is because at the time of adolescence there is rapid growth and changes in physiological maturity in connection with puberty.

The nutritional needs of adolescents need to be considered. This is because the nutritional needs of adolescents increase due to increased growth and development. In addition, changing lifestyles and eating habits will also affect adolescent nutritional intake. The adolescent age group is preoccupied with a lot of physical activity. Therefore, the needs of calories, protein, and micronutrients in adolescence need to be considered.

Currently, many teenagers like fast food or fast food. Adolescents who have high social activities tend to show interactions with peers. In big cities, many groups of teenagers eat together at restaurants that provide fast food or fast food. Fast food comes from western countries which generally have high fat and calorie content. If consumed in large quantities every day, it can cause obesity. Obesity or overweight can cause other nutritional problems.

Fast food or fast food is also known to the public as junk food. Junk food is defined as junk food or non-nutritive food. The term means to indicate foods that are considered to have no nutritional value for the body. Eating junk food is not only useless but can also be detrimental to health. Health problems due to eating junk food such as obesity or overweight, diabetes, hypertension, coronary heart disease, stroke, cancer, and so on.

Fast food and junk food are becoming popular because they are fast, widely available, easy to obtain, and have good taste. However, eating habits by consuming fast food or excess junk food will have a bad impact on health, both for children, adolescents, and adults. Fast food can increase the risk of several diseases, such as obesity, diabetes, hypertension, and blood lipid disorders or dyslipidemia. In addition, fast food for a long time will also affect dental health. Fast food that has a high sugar content can cause dental caries or cavities19. Based on the description that has been described previously, it will be discussed in more depth about what factors influence the behavior of adolescents to consume fast food. In addition, it will also discuss the health effects of the habit of consuming fast food.

\section{METHODS}

This study uses a qualitative research method with a phenomenological approach. Collecting data from in-depth interviews which were then copied in the form of words to four informants from different 
E-ISSN: 2808-5361 http://e-journal.fkmumj.ac.id/
Proceeding The First

Muhammadiyah Internasional-

Public Health and Medicine

Conference

classes. The source triangulation design approach was carried out on four informants to determine Student Perceptions About Fast Food Consumption Behavior at SMA Nusantara Plus. The data collected in this study were the characteristics of the respondents, knowledge about fast food, attitudes, parental income, pocket money, peer influence, and the influence of mass media. The variables in this study include independent variables such as knowledge about fast food, attitudes, parental income, pocket money, peers, and mass media. The variable is the consumption of fast food.

\section{RESULTS AND DISCUSSIONS}

Table 1. Fast Food Interview Matrix in Adolescents

Inisial Informan: Laila Zafira

Jenis kelamin: Perempuan

Usia: 16 Tahun

Kelas: 1 SMA

Alamat: Perumahan Ciputat Baru, Pondok Ranji, Ciputat Timur

\begin{tabular}{|c|c|c|}
\hline QUESTION & INFORMANT ANSWERS & CONCLUSION OF ANSWER \\
\hline \multicolumn{3}{|l|}{ A. KNOWLEDGE } \\
\hline What do you know about fast food? & Fast food & $\begin{array}{l}\text { Respondents know that fast food } \\
\text { is fast food. }\end{array}$ \\
\hline $\begin{array}{l}\text { Do you know the nutritional content } \\
\text { contained in fast food? }\end{array}$ & You know a little & $\begin{array}{l}\text { Respondents know little about } \\
\text { the nutritional content of fast } \\
\text { food }\end{array}$ \\
\hline $\begin{array}{l}\text { What are the effects if you consume } \\
\text { fast food too often? }\end{array}$ & $\begin{array}{l}\text { So fat, not healthy also make the body } \\
\text { if you often eat fast food }\end{array}$ & $\begin{array}{l}\text { Respondents know dampak } \\
\text { often eat fast food that can be fat }\end{array}$ \\
\hline \multicolumn{3}{|l|}{ B. ATTITUDE } \\
\hline $\begin{array}{l}\text { What are the advantages / advantages } \\
\text { of fast food compared to other types } \\
\text { of food? }\end{array}$ & Delicious, addictive & $\begin{array}{l}\text { According to respondents, the } \\
\text { advantages of fast food are tasty } \\
\text { and addictive. }\end{array}$ \\
\hline $\begin{array}{l}\text { If invited to eat, you prefer foods } \\
\text { such as pizza, KFC or gado-gado? }\end{array}$ & $\begin{array}{l}\text { Yes, it must be in kfc's rich restaurant, } \\
\text { Mcd }\end{array}$ & $\begin{array}{l}\text { Respondents prefer thenn in the } \\
\text { restaurant }\end{array}$ \\
\hline $\begin{array}{l}\text { What fast food restaurants do you } \\
\text { visit most often? Why? }\end{array}$ & $\begin{array}{l}\text { Often to Mcd, the problem is dekat } \\
\text { from school so often gather to get to } \\
\text { the task together temanthere }\end{array}$ & $\begin{array}{l}\text { The restaurant frequented by } \\
\text { respondents is Mcd. }\end{array}$ \\
\hline $\begin{array}{l}\text { How do you feel when you eat fast } \\
\text { food compared to other types of } \\
\text { food? }\end{array}$ & It tastes better and practical. & $\begin{array}{l}\text { Respondents feel good and } \\
\text { practically consume fast food }\end{array}$ \\
\hline \multicolumn{3}{|c|}{ C. IMPORTANT PEOPLE AS REFERENCES } \\
\hline $\begin{array}{l}\text { Who is your driver / role model so } \\
\text { often consume fast food? }\end{array}$ & Friends are usually the ones who invite & $\begin{array}{l}\text { Responden sering mengkonsumsi } \\
\text { fast food karena teman-temannya }\end{array}$ \\
\hline $\begin{array}{l}\text { Does the school usually invite } \\
\text { students to eat at fast food restaurants } \\
\text { when holding an event / activity? }\end{array}$ & $\begin{array}{l}\text { No, the school is also a rare country } \\
\text { outside the event. }\end{array}$ & $\begin{array}{l}\text { Schools where respondents rarely } \\
\text { hold events at fast food } \\
\text { restaurants }\end{array}$ \\
\hline \multicolumn{3}{|l|}{ D. FACILITIES } \\
\hline $\begin{array}{l}\text { What is access to a fast food } \\
\text { restaurant? }\end{array}$ & Biasanya naik ojek online & $\begin{array}{l}\text { Regular respondents to fast food } \\
\text { places using ojek online }\end{array}$ \\
\hline $\begin{array}{l}\text { What is the service at a fast food } \\
\text { restaurant? }\end{array}$ & $\begin{array}{l}\text { Okay, quick service, but there's also } \\
\text { judes }\end{array}$ & $\begin{array}{l}\text { Service at fast food restaurants } \\
\text { according to respondents is quite }\end{array}$ \\
\hline
\end{tabular}


E-ISSN: 2808-5361 http://e-journal.fkmumj.ac.id/
Proceeding The First

Muhammadiyah Internasional-

Public Health and Medicine

Conference

\begin{tabular}{|l|l|l|}
\hline \multicolumn{1}{|c|}{ QUESTION } & \multicolumn{1}{|c|}{ INFORMANT ANSWERS } & CONCLUSION OF ANSWER \\
\hline $\begin{array}{l}\text { What makes you comfortable in a fast } \\
\text { food restaurant? }\end{array}$ & $\begin{array}{l}\text { The place is good adem there is ac, } \\
\text { there is wifi, comfortable bgt deh to sit } \\
\text { while nugas, plus the food is also good }\end{array}$ & $\begin{array}{l}\text { Rood and fast service } \\
\text { fast food restaurants }\end{array}$ \\
\hline $\begin{array}{l}\text { Do your parents have limits on eating } \\
\text { food? }\end{array}$ & $\begin{array}{l}\text { Yes si, but still often to fast food } \\
\text { restaurant diem-diem hehe }\end{array}$ & $\begin{array}{l}\text { Respondents are still often diem } \\
\text { diem to fast food restaurants }\end{array}$ \\
\hline $\begin{array}{l}\text { What food is usually provided at } \\
\text { home? }\end{array}$ & $\begin{array}{l}\text { Usually if at home there are vegetables, } \\
\text { tempeh tofu, chicken or fish ga }\end{array}$ & $\begin{array}{l}\text { Food commonly served at home } \\
\text { vegetables and side dishes }\end{array}$ \\
\hline $\begin{array}{l}\text { Is it at home fast food type commonly } \\
\text { served? }\end{array}$ & $\begin{array}{l}\text { Yes, but rarely. You cook more often } \\
\text { than buy. }\end{array}$ & At home rarely buy fast food \\
\hline E. MONEY & 30-40 thousand & $\begin{array}{l}\text { Respondents used to be given } \\
\text { snack money around 30-40 } \\
\text { thousand }\end{array}$ \\
\hline $\begin{array}{l}\text { How much pocket money do parents } \\
\text { give? }\end{array}$ & $\begin{array}{l}\text { Yes, if the weekend often to fast food } \\
\text { restaurants are also the same family. }\end{array}$ & $\begin{array}{l}\text { Responders every week to fast } \\
\text { food restaurants with family }\end{array}$ \\
\hline F. CULTURE & Usually once a week. \\
\hline $\begin{array}{l}\text { In addition to eating food, do you and family often make fast food } \\
\text { restaurants as a place to gather with } \\
\text { family? }\end{array}$ & $\begin{array}{l}\text { Do you and your family often make } \\
\text { fast food restaurants a place to } \\
\text { celebrate an event? }\end{array}$ & Once, the time of adek's birthday \\
\hline $\begin{array}{l}\text { How many times a week do you eat } \\
\text { fast food? }\end{array}$ & $\begin{array}{l}\text { Depends on the money. But usually a } \\
\text { week there is a week to eat fast food. }\end{array}$ & $\begin{array}{l}\text { Respondents at least once a week } \\
\text { to fast food restaurants }\end{array}$ \\
\hline
\end{tabular}

Table 2. Fast Food Interview Matrix in Adolescents from Informant 2

Initials Informant: Safira Amerta

Gender: Female

Age: 17 years old

Classes: 2 high schools

Address: Legosa Raya Street, East Ciputat, South Tanggerang

\begin{tabular}{|l|l|l|}
\hline \multicolumn{1}{|c|}{ QUESTION } & \multicolumn{1}{|c|}{ INFORMANT ANSWERS } & CONCLUSION OF ANSWER \\
\hline A. KNOWLEDGE & Food that can be eaten & $\begin{array}{l}\text { Respondents know about fast } \\
\text { food }\end{array}$ \\
\hline What do you know about fast food? & $\begin{array}{l}\text { Respondents know the basic } \\
\text { nutritional content of fast food }\end{array}$ \\
\hline $\begin{array}{l}\text { Do you know the nutritional content } \\
\text { contained in fast food? }\end{array}$ & You know, but the basics. \\
\hline $\begin{array}{l}\text { What are the effects if you consume fast } \\
\text { food too often? }\end{array}$ & $\begin{array}{l}\text { Not healthy for the body, can make } \\
\text { fat continue spotty }\end{array}$ & $\begin{array}{l}\text { Respondents know the impact of } \\
\text { fast food }\end{array}$ \\
\hline B. ATTITUDE & $\begin{array}{l}\text { Respondents answered fast food } \\
\text { more practically }\end{array}$ \\
\hline $\begin{array}{l}\text { What are the advantages / advantages of } \\
\text { fast food compared to other types of } \\
\text { food? }\end{array}$ & $\begin{array}{l}\text { Tasty, not tired of having to cook, } \\
\text { affordable }\end{array}$ & Respondents prefer KFC. \\
\hline $\begin{array}{l}\text { If invited to eat, you prefer foods such as } \\
\text { pizza, KFC or gado-gado? }\end{array}$ & It's certainly KFC, MCD. \\
\hline $\begin{array}{l}\text { What fast food restaurants do you visit } \\
\text { most often? Why? }\end{array}$ & $\begin{array}{l}\text { Often MCD because it is more } \\
\text { deket ni than komplek, out of the } \\
\text { complex sampai }\end{array}$ & $\begin{array}{l}\text { Respondents often go to fast food } \\
\text { restaurants because they are } \\
\text { close to home. }\end{array}$ \\
\hline How do you feel when you eat fast food & Delicious, not complicated & Respondents feel good and do \\
\hline
\end{tabular}


E-ISSN: 2808-5361 http://e-journal.fkmumj.ac.id/
Proceeding The First

Muhammadiyah Internasional-

Public Health and Medicine

Conference

\begin{tabular}{|c|c|c|}
\hline QUESTION & INFORMANT ANSWERS & CONCLUSION OF ANSWER \\
\hline compared to other types of food? & & not bother when eating fast food \\
\hline \multicolumn{3}{|c|}{ C. IMPORTANT PEOPLE AS REFERENCES } \\
\hline $\begin{array}{l}\text { Who is your driver / role model so often } \\
\text { consume fast food? }\end{array}$ & $\begin{array}{l}\text { Teman, sometimes mama is also } \\
\text { the one whoclimbed }\end{array}$ & $\begin{array}{l}\text { His friends and mother often } \\
\text { invited him to restaurants. }\end{array}$ \\
\hline $\begin{array}{l}\text { Does the school usually invite students to } \\
\text { eat at fast food restaurants when holding } \\
\text { an event / activity? }\end{array}$ & $\begin{array}{l}\text { Before there was a pandemic there } \\
\text { were often school events outside. }\end{array}$ & $\begin{array}{l}\text { School respondents often held } \\
\text { outdoor events before the } \\
\text { pandemic. }\end{array}$ \\
\hline \multicolumn{3}{|l|}{ D. FACILITIES } \\
\hline What is access to a fast food restaurant? & $\begin{array}{l}\text { Usually riding a motorcycle, } \\
\text { sometimes walking }\end{array}$ & $\begin{array}{l}\text { Respondents chose to take a } \\
\text { motorcycle and walk to fast food } \\
\text { restaurants. }\end{array}$ \\
\hline $\begin{array}{l}\text { What is the service at a fast food } \\
\text { restaurant? }\end{array}$ & $\begin{array}{l}\text { Good, friendly, the service is also } \\
\text { good. }\end{array}$ & $\begin{array}{l}\text { Service according to respondents } \\
\text { is friendly and fast }\end{array}$ \\
\hline $\begin{array}{l}\text { What makes you comfortable in a fast } \\
\text { food restaurant? }\end{array}$ & $\begin{array}{l}\text { The food is good, the place is } \\
\text { comfortable, there is wifi too. }\end{array}$ & $\begin{array}{l}\text { Respondents feel comfortable } \\
\text { when in fast food restaurants }\end{array}$ \\
\hline $\begin{array}{l}\text { Do your parents have limits on eating } \\
\text { food? }\end{array}$ & Yes, but sometimes I eat too. & $\begin{array}{l}\text { Parents of respondents to } \\
\text { consume fast food }\end{array}$ \\
\hline What food is usually provided at home? & $\begin{array}{l}\text { Biasanya kalo dirumah ya mba } \\
\text { masak sayuran }\end{array}$ & Respondents provided vegetables \\
\hline $\begin{array}{l}\text { Is it at home fast food type commonly } \\
\text { served? }\end{array}$ & $\begin{array}{l}\text { Often, because mom and dad work } \\
\text { so sometimes they go home like to } \\
\text { bring fast food too }\end{array}$ & Respondents often eat fast food. \\
\hline \multicolumn{3}{|l|}{ E. MONEY } \\
\hline $\begin{array}{l}\text { How much pocket money do parents } \\
\text { give? }\end{array}$ & $50-100$ thousand & $\begin{array}{l}\text { Respondents' allowances } 50 \text { to } \\
100 \text { thousand }\end{array}$ \\
\hline \multicolumn{3}{|l|}{ F. CULTURE } \\
\hline $\begin{array}{l}\text { In addition to eating food, do you and } \\
\text { your family often make fast food } \\
\text { restaurants as a place to gather with } \\
\text { family? }\end{array}$ & $\begin{array}{l}\text { Often but because the pandemic } \\
\text { becomes less to eat out }\end{array}$ & $\begin{array}{l}\text { Respondents often eat out with } \\
\text { their families. }\end{array}$ \\
\hline $\begin{array}{l}\text { Do you and your family often make fast } \\
\text { food restaurants a place to celebrate an } \\
\text { event? }\end{array}$ & Ever, almost every birthday & $\begin{array}{l}\text { Respondents often eat out with } \\
\text { their families. }\end{array}$ \\
\hline $\begin{array}{l}\text { How many times a week do you eat fast } \\
\text { food? }\end{array}$ & $\begin{array}{l}\text { Not necessarily Sometimes eating } \\
\text { fast food all day. }\end{array}$ & Respondents often eat fast food. \\
\hline
\end{tabular}

\section{Table 3. Fast Food Interview Matrix in Adolescents from Informant 3}

Inisial Informan: Shalsabilla Namira

Jenis kelamin: Perempuan

Usia: 17 Tahun

Kelas: 2 SMA

Alamat: Jalan Tarumanegara, Ciputat Timur, Tanggerang Selatan

\begin{tabular}{|l|l|l|}
\hline \multicolumn{1}{|c|}{ QUESTION } & \multicolumn{1}{|c|}{ INFORMANT ANSWERS } & CONCLUSION OF ANSWER \\
\hline A. KNOWLEDGE & Fast food & $\begin{array}{l}\text { Respondents already know fast food } \\
\text { is fast food. }\end{array}$ \\
\hline What do you know about fast food? & Respondents know little about the \\
\hline Do you know the nutritional content & I know, but I don't know a lot
\end{tabular}




\begin{tabular}{|c|c|c|}
\hline QUESTION & INFORMANT ANSWERS & CONCLUSION OF ANSWER \\
\hline contained in fast food? & & nutritional content in fast food \\
\hline $\begin{array}{l}\text { What are the effects if you consume fast } \\
\text { food too often? }\end{array}$ & It could be fat, not healthy too. & $\begin{array}{l}\text { Respondents know the impact of } \\
\text { eating fast food often }\end{array}$ \\
\hline \multicolumn{3}{|l|}{ B. ATTITUDE } \\
\hline $\begin{array}{l}\text { What are the advantages / advantages of } \\
\text { fast food compared to other types of } \\
\text { food? }\end{array}$ & It's good to eat fast food. & $\begin{array}{l}\text { According to respondents the } \\
\text { advantages of fast food are delicious }\end{array}$ \\
\hline $\begin{array}{l}\text { If invited to eat, you prefer foods such } \\
\text { as pizza, KFC or gado-gado? }\end{array}$ & $\begin{array}{l}\text { Prefer Mcd KFC because the } \\
\text { chicken is delicious addictive }\end{array}$ & $\begin{array}{l}\begin{array}{l}\text { Respondents were more fed at } \\
\text { restaurants. }\end{array} \\
\end{array}$ \\
\hline $\begin{array}{l}\text { What fast food restaurants do you visit } \\
\text { most often? Why? }\end{array}$ & $\begin{array}{l}\text { Often it's to Mcd, the problem is } \\
\text { deckat from home }\end{array}$ & $\begin{array}{l}\text { The restaurant frequented by } \\
\text { respondents is Mcd. }\end{array}$ \\
\hline $\begin{array}{l}\text { How do you feel when you eat fast food } \\
\text { compared to other types of food? }\end{array}$ & Better than non-fast food & $\begin{array}{l}\text { Respondents feel better consuming } \\
\text { fast food }\end{array}$ \\
\hline \multicolumn{3}{|c|}{ C. IMPORTANT PEOPLE AS REFERENCES } \\
\hline $\begin{array}{l}\text { Who is your driver / role model so often } \\
\text { consume fast food? }\end{array}$ & Invited by friends & $\begin{array}{l}\text { Respondents are often invited by } \\
\text { friends. }\end{array}$ \\
\hline $\begin{array}{l}\text { Does the school usually invite students } \\
\text { to eat at fast food restaurants when } \\
\text { holding an event / activity? }\end{array}$ & Never & $\begin{array}{l}\text { Respondents never held an event at a } \\
\text { fast food restaurant }\end{array}$ \\
\hline \multicolumn{3}{|l|}{ D. FACILITIES } \\
\hline What is access to a fast food restaurant? & $\begin{array}{l}\begin{array}{l}\text { Usually riding my } \\
\text { motorcycle }\end{array}\end{array}$ & $\begin{array}{l}\text { Regular respondents to fast food } \\
\text { places ride their own vehicles }\end{array}$ \\
\hline $\begin{array}{l}\text { What is the service at a fast food } \\
\text { restaurant? }\end{array}$ & Friendly, kind, the service is fast & $\begin{array}{l}\text { Service at fast food restaurants } \\
\text { according to respondents is friendly, } \\
\text { good and the service is fast }\end{array}$ \\
\hline $\begin{array}{l}\text { What makes you comfortable in a fast } \\
\text { food restaurant? }\end{array}$ & $\begin{array}{l}\text { The place is good for the same } \\
\text { nteman, there is wifi can also do } \\
\text { tasks as well }\end{array}$ & $\begin{array}{l}\text { Respondents feel comfortable being } \\
\text { restored fast food }\end{array}$ \\
\hline $\begin{array}{l}\text { Do your parents have limits on eating } \\
\text { food? }\end{array}$ & $\begin{array}{l}\text { yes, but like to go there to the } \\
\text { knowledge of parents right to } \\
\text { play }\end{array}$ & $\begin{array}{l}\text { Respondents still often silent to fast } \\
\text { food restaurants }\end{array}$ \\
\hline What food is usually provided at home? & $\begin{array}{l}\text { Chicken, tempeh, fish, } \\
\text { vegetables }\end{array}$ & $\begin{array}{l}\text { Food that is usually served at home } \\
\text { vegetables and side dishes }\end{array}$ \\
\hline $\begin{array}{l}\text { Is it at home fast food type commonly } \\
\text { served? }\end{array}$ & Yes, but more often cook. & $\begin{array}{l}\text { At home respondents rarely buy fast } \\
\text { food more often cooked themselves }\end{array}$ \\
\hline \multicolumn{3}{|l|}{ E. MONEY } \\
\hline $\begin{array}{l}\text { How much pocket money do parents } \\
\text { give? }\end{array}$ & $25-30$ thousand & $\begin{array}{l}\text { Ordinary respondents get an } \\
\text { allowance of 25-30 thousand }\end{array}$ \\
\hline \multicolumn{3}{|l|}{ F. CULTURE } \\
\hline $\begin{array}{l}\text { In addition to eating food, do you and } \\
\text { your family often make fast food } \\
\text { restaurants as a place to gather with } \\
\text { family? }\end{array}$ & $\begin{array}{l}\text { Yes, if the weekend family } \\
\text { gathering }\end{array}$ & $\begin{array}{l}\text { Responders every week to fast food } \\
\text { restaurants with family }\end{array}$ \\
\hline $\begin{array}{l}\text { Do you and your family often make fast } \\
\text { food restaurants a place to celebrate an } \\
\text { event? }\end{array}$ & Ever, birthday time teman & $\begin{array}{l}\text { Respondents once held an event at a } \\
\text { fast food restaurant }\end{array}$ \\
\hline $\begin{array}{l}\text { How many times a week do you eat fast } \\
\text { food? }\end{array}$ & $\begin{array}{l}\text { Depending on whether there is } \\
\text { stillanan or not sim money, or } \\
\text { not bought mom }\end{array}$ & $\begin{array}{l}\text { Respond at least once a week to fast } \\
\text { food restaurants }\end{array}$ \\
\hline
\end{tabular}

Table 4. Fast Food Interview Matrix in Adolescents from Informant 4 
E-ISSN: 2808-5361 http://e-journal.fkmumj.ac.id/
Proceeding The First

Muhammadiyah Internasional-

Public Health and Medicine

Conference

Initials Informant: Malika kirana

Gender: Female

Age: 18 years old

Class: 3 high schools

Address: bintaro sector 9, south Tangerang

\begin{tabular}{|c|c|c|}
\hline QUESTION & INFORMANT ANSWERS & CONCLUSION OF ANSWER \\
\hline \multicolumn{3}{|l|}{ A. KNOWLEDGE } \\
\hline What do you know about fast food? & Fast food & Respondents know about fast food \\
\hline $\begin{array}{l}\text { Do you know the nutritional content } \\
\text { contained in fast food? }\end{array}$ & Less know & $\begin{array}{l}\text { Respondents know less about the } \\
\text { content in fast food }\end{array}$ \\
\hline $\begin{array}{l}\text { What are the effects if you consume fast } \\
\text { food too often? }\end{array}$ & $\begin{array}{l}\text { the body becomes often sick, } \\
\text { making the body fat }\end{array}$ & $\begin{array}{l}\text { Respondents know the impact of } \\
\text { consuming fast food }\end{array}$ \\
\hline \multicolumn{3}{|l|}{ B. ATTITUDE } \\
\hline $\begin{array}{l}\text { What are the advantages / advantages of fast } \\
\text { food compared to other types of food? }\end{array}$ & $\begin{array}{l}\text { The advantages are practical to } \\
\text { eat. } \\
\text { The drawbacks are not there } \\
\text { because fast food is all good. }\end{array}$ & $\begin{array}{l}\text { Respondents know the advantages } \\
\text { and disadvantages of fast food }\end{array}$ \\
\hline $\begin{array}{l}\text { If invited to eat, you prefer foods such as } \\
\text { pizza, KFC or gado-gado? }\end{array}$ & $\begin{array}{l}\text { prefer to eat in restaurants such } \\
\text { as solaria, MCD etc. }\end{array}$ & $\begin{array}{l}\text { Respondents chose to eat at the } \\
\text { restaurant }\end{array}$ \\
\hline $\begin{array}{l}\text { What fast food restaurants do you visit most } \\
\text { often? Why? }\end{array}$ & $\begin{array}{l}\text { Usually mcd, because the price } \\
\text { is affordable. }\end{array}$ & $\begin{array}{l}\text { Respondents used to eat at MCD at } \\
\text { an affordable price }\end{array}$ \\
\hline $\begin{array}{l}\text { How do you feel when you eat fast food } \\
\text { compared to other types of food? }\end{array}$ & $\begin{array}{l}\text { if fast food tastes savory that } \\
\text { If home-cooked food usually } \\
\text { tastes mostly bland }\end{array}$ & $\begin{array}{l}\text { Respondents said fast food is } \\
\text { better than home-cooked food }\end{array}$ \\
\hline \multicolumn{3}{|c|}{ C. IMPORTANT PEOPLE AS REFERENCES } \\
\hline $\begin{array}{l}\text { Who is your driver / role model so often } \\
\text { consume fast food? }\end{array}$ & Peers & $\begin{array}{l}\text { Respondents said peers who } \\
\text { became role models }\end{array}$ \\
\hline $\begin{array}{l}\text { Does the school usually invite students to } \\
\text { eat at fast food restaurants when holding an } \\
\text { event / activity? }\end{array}$ & No & $\begin{array}{l}\text { Respondents never held fast food } \\
\text { meals at school events }\end{array}$ \\
\hline \multicolumn{3}{|l|}{ D. FACILITIES } \\
\hline What is access to a fast food restaurant? & riding a motorcycle & $\begin{array}{l}\text { Road access to the respondent's } \\
\text { dining place is to ride a motorcycle }\end{array}$ \\
\hline What is the service at a fast food restaurant? & Pretty friendly & $\begin{array}{l}\text { Respondents said the service at the } \\
\text { restaurant was quite friendly. }\end{array}$ \\
\hline $\begin{array}{l}\text { What makes you comfortable in a fast food } \\
\text { restaurant? }\end{array}$ & $\begin{array}{l}\text { The place is comfortable, there } \\
\text { is wifi, and many plugs for } \\
\text { charging }\end{array}$ & $\begin{array}{l}\text { Respondents said all facilities in } \\
\text { the restaurant are quite convenient. }\end{array}$ \\
\hline Do your parents have limits on eating food? & Certainly not & $\begin{array}{l}\text { Respondents said there was no } \\
\text { limit to eating fast food. }\end{array}$ \\
\hline What food is usually provided at home? & $\begin{array}{l}\text { Various kinds of foods such as } \\
\text { vegetables, stir-fry, fried fried } \\
\text { foods }\end{array}$ & $\begin{array}{l}\text { Respondents said a lot of food was } \\
\text { provided at home. }\end{array}$ \\
\hline $\begin{array}{l}\text { Is it at home fast food type commonly } \\
\text { served? }\end{array}$ & $\begin{array}{l}\text { Sometimes my mom is lazy to } \\
\text { cook. }\end{array}$ & $\begin{array}{l}\text { Respondents said they like to serve } \\
\text { fast food at home if they are lazy } \\
\text { to cook. }\end{array}$ \\
\hline \multicolumn{3}{|l|}{ E. MONEY } \\
\hline How much pocket money do parents give? & 35 thousand & $\begin{array}{l}\text { Respondents said the money per } \\
\text { day } 35 \text { thousand }\end{array}$ \\
\hline \multicolumn{3}{|l|}{ F. CULTURE } \\
\hline In addition to eating food, do you and your & Yes often & Respondents said they often eat at \\
\hline
\end{tabular}




\begin{tabular}{|l|l|l|}
\hline \multicolumn{1}{|c|}{ QUESTION } & INFORMANT ANSWERS & CONCLUSION OF ANSWER \\
\hline $\begin{array}{l}\text { family often make fast food restaurants as a } \\
\text { place to gather with family? }\end{array}$ & fast food with family. \\
\hline $\begin{array}{l}\text { Do you and your family often make fast } \\
\text { food restaurants a place to celebrate an } \\
\text { event? }\end{array}$ & Never & $\begin{array}{l}\text { Respondents said they never } \\
\text { celebrated the event at a fast food } \\
\text { venue. }\end{array}$ \\
\hline $\begin{array}{l}\text { How many times a week do you eat fast } \\
\text { food? }\end{array}$ & Once a week, usually. & $\begin{array}{l}\text { Respondents said once a week eat } \\
\text { fast food }\end{array}$ \\
\hline
\end{tabular}

Knowledge can influence a person's behavior, including knowledge about nutrition that can affect food consumption behavior. Adolescent knowledge relates to the existence of information facilities, such as libraries in schools, computer laboratories, and multimedia rooms to find the latest information. Lack of nutritional knowledge and consuming non-nutritive foods can cause problems with low levels of nutrients in the body.

The majority of teenagers get support from their peers to eat fast food 4-27 times in one month. In this study, based on the FGD conducted, peer invitation was one of the factors that influenced teenagers to choose fast food or fast food compared to other foods.

Fast food or junk food restaurants are usually a gathering place with family or friends. A relaxed and comfortable place to eat, as well as an attractive layout, coupled with free wifi, are the main attraction for consumers to eat at fast-food restaurants.

Fast service and practical presentation also influence people to consume fast food. For teenagers, consuming fast food is an option because of the limited time they have.

One of the reasons you often eat fast food is because it tastes good (Pratiwi, 2018). Teenagers who are accustomed to consuming fast food assume that fast food is food that has a good taste, is easy to obtain, and can arouse appetite. Fast food and junk food are generally liked by the public, including teenagers because it has a good taste. The factor that causes fast food to have a good taste is the high content of oil, salt, and sugar. Fast food restaurants, in general, are competing to make new variations of food with good taste so that it suits people's tastes.

Income in a group that has increased will also affect lifestyle changes, especially in the diet. People's eating patterns are changing in an unhealthy direction, such as eating fast food. The income of parents will also affect the pocket money received by teenagers. The availability of pocket money received by teenagers will affect the pattern of fast food consumption. The bigger the pocket money that teenagers have, the more and more teenagers consume fast food.

Low prices and large portions offered by fast-food restaurants also affect the habit of consuming fast food. In addition, the number of discounts offers by fast-food restaurants also increases people's 
E-ISSN: 2808-5361 http://e-journal.fkmumj.ac.id/
Proceeding The First Muhammadiyah InternasionalPublic Health and Medicine

Conference

desire to buy these foods. Discounts and savings packages offered make consumers, especially teenagers, increasingly interested in coming and consuming fast food.

The brand of a fast-food restaurant can influence someone to consume this fast food. Teenagers tend to eat food that has a well-known brand or brand as self-expression in association and becomes a prestigious event. The thing that is becoming a trend for teenagers today is to take pictures at restaurants with the brand to show their friends through social media. This shows that they have visited and eaten at restaurants with that brand.

\section{CONCLUSION AND SUGGESTIONS}

Fast food is food that is not good for teenagers if it is consumed too often. The number of teenagers who consume fast food is caused by several factors, including knowledge, peer influence, comfortable places to gather, fast and practical, pocket money, low prices, and brands of fast food. If fast food is consumed in excess, it will have an impact on adolescent health. These health problems are obesity, increasing risk factors for hypertension, diabetes, cancer, heart disease, and stroke.

\section{REFERENCES}

Adriani, M. \& Wirjatmadi, B. 2012. Peranan Gizi dalam Siklus Kehidupan. Jakarta: Prenamedia Group.

Almatsier, S. 2009. Prinsip Dasar Ilmu Gizi. Jakarta: PT Gramedia Pustaka Utama.

Arya, G. \& Mishra, S. 2013. Effects of Junk Food \& Beverages on Adolescent's Health - A Review Article. Journal of Nursing and Health Science Vol. 1 No. 6.

Bahadoran, Z., Mirmiran, P. \& Azizi, F. 2015. Fast Food Pattern and Cardiometabolic Disorders: A Review of Current Studies. Health Promotion Perspective Vol. 5 No. 4

Khairiyah, E.L. 2016. Pola Makan Mahasiswa Fakultas Kedokteran dan Ilmu Kesehatan (FKIK) UIN Syarif Hidayatullah Jakarta Tahun 2016. Skripsi. Universitas Islam Negeri Syarif Hidayatullah Jakarta. 
Volume I Tahun 2021

November 2021
E-ISSN: 2808-5361

http://e-journal.fkmumj.ac.id/
Proceeding The First Muhammadiyah InternasionalPublic Health and Medicine Conference

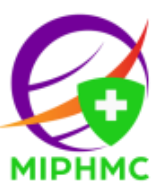

